Original Paper http://ajol.info/index.php/ijbcs http://indexmedicus.afro.who.int

\title{
Vegetation improvement and soil biological quality in the Sahel of Burkina Faso
}

\author{
Ouango Maurice SAVADOGO ${ }^{1,2^{*}}$, Korodjouma OUATTARA ${ }^{1}$, Issa OUEDRAOGO ${ }^{1}$, \\ Séraphine SAWADOGO/KABORE ${ }^{3}$, Mamoudou TRAORE ${ }^{1}$, Jennie BARRON ${ }^{4}$, \\ Line GORDON ${ }^{4}$, Souleymane PARE ${ }^{1}$ and Nabsanna Prosper ZOMBRE ${ }^{2}$ \\ ${ }^{I}$ Institut de l'Environnement et de Recherches Agricoles, 04 BP: 8645 Ouagadougou 04, Burkina Faso. \\ ${ }^{2}$ Université de Ouagadougou, Unité de Formation et de Recherche en Sciences de la Vie et de la Terre, \\ Laboratoire de Sciences du Sol et de l'Environnement, 03BP: 7021 Ouagadougou 03, Burkina Faso. \\ ${ }^{3}$ CAP-PPAAO/WAAPP Burkina, 01 BP 6285 Ouagadougou 01, Burkina Faso. \\ ${ }^{4}$ International Water Management Institute (IWMI), \\ 127 Sunil Mawatha Pelawatte, Battaramulla, Sri Lanka. \\ ${ }^{*}$ Corresponding author; E-mail: savadogoouango@yahoo.fr; Tel: (+226) 60646562
}

\section{ACKNOWLEDGEMENTS}

This study was funded by the Re-greening project with the partnership of the University of Stockholm. Our thanks go to WAAPP / WAAPP (West Africa Agricultural Productivity program) Burkina Faso for the financial assistance.

\begin{abstract}
Soil living environment contains macro-fauna that play important role in the soil structure and chemical composition, the degradation process of organic matter and in the resilience of ecosystems. Few studies evaluated the impact of the "re-greening" trend observed in the Sahel on soil biological quality. The objective of this study is to assess the impact of the "re-greening" of the Sahel on soil macro-fauna population and diversity. The method of Tropical Soil Biology and Fertility (TSBF) was used to assess macro-fauna abundance and diversity in different land use types (cropland, shallow land, degraded land and forest). Four sites were selected, in the Sahelian zone of Burkina Faso, with contrasted Normalized Difference Vegetation Index (NDVI). In each site, four repetitions were taken for each land use type. In total, 64 plots samples were used to assess the abundance of macro-fauna. Results showed that there were more individuals $(64.92 \%)$ and higher macro-fauna density in re-greening zones compared to the degrading zones. There was dominance of Arthropoda phylum (60.85\%), Insecta class (59.03\%) and Isoptera order (46.97\%) in macro-fauna population. There were more species in the shallow land and cropland in re-greening zones and all trophic groups are represented in all sites. Despite this abundance, composition and diversity, it was observed that the re-greening processes have not significantly improved soil biological quality. It is concluded that vegetation improvement might be at the beginning stage in the Sahel, especially in croplands, and clear change of soil biological quality is not perceptible but may be tangible in the future.

() 2016 International Formulae Group. All rights reserved.
\end{abstract}

Keywords: Macro-fauna, ecosystem, soil quality, re-greening, degradation. 


\section{INTRODUCTION}

Soil, water, climate, flora and fauna constitute the basic natural resources on which human depend for his well-being and survival. Soil is the most important natural resource (Gajbhiye and Mandal, 2000); therefore, it is necessary to know its potential and limitations to support the activities and production systems.

The soil living organisms of different shapes and sizes contribute to soil fertility which is important for a sustainable agriculture (Ouedraogo et al., 2014). In the living environment, this system contributes to the vital function as regulating the dynamics of soil organic matter, soil carbon sequestration, modification of the physical structure of soil and it increases the amount and effectiveness of nutrients acquisition by plants (Lavelle et al., 2001; Lavelle, 2002). However, the abundance and distribution of their populations are influenced by vegetation, soil conditions, cultural practices, crop type and also the effect of fire (Hallaire et al., 2004; Tondoh, 2008; Traore et al., 2012). Soil macro-fauna improves soil productivity and contributes to the sustainability of all ecosystems (Milau et al., 2015).

During the three last decades, there has been a controversy on the state of the Sahel ecosystems. Although many studies supported that the Sahel is continuously degrading (Hountondji et al., 2006; Ozer et al., 2007; Ozer, 2009), some others argued that there is a sign of re-greening in some specific zones in the Sahel (Anyamba and Tucker, 2005; Hickler et al., 2005; Fensholt et al., 2012; Dardel et al., 2014; Savadogo et al., 2015; Savadogo et al., 2016). The studies of Eklundh and Olsson (2003), Anyamba and Tucker (2005), Olsson et al. (2005), Hickler et al. (2005) and Turcker et al. (2005) on the NDVI values in the Sahel have shown that in Burkina Faso, the areas around Ouahigouya are in re-greening state while in Kaya, the degradation process is persisting. The regreening is caused by, but not limited to, the return of rainfall, human activities (Botoni et Reij, 2009; Sendzimir et al., 2011) contributing to improve environment. This environmental change may contribute to the improvement of the communities of the pedofauna. Studies of re-greening are most interested in rainfall, vegetation, human activity and soil conditions (Eklundh and Olsson, 2003; Herrmann et al., 2005; Olsson et al., 2005; Botoni et Reij, 2009; Sendzimir et al., 2011; Ouedraogo et al., 2014). Yet, there is no study that has focused on soil macrofauna to find out what could happen to soil biological quality in the context of re-greening and/or continuous degradation processes in the Sahel.

This study was focused on the assessment of the abundance, composition, diversity and trophic functions that belong to soil macro-fauna in two contrasted ecosystems in the Sahel of Burkina Faso. More specifically, the research explored the contribution of the re-greening to the soil macro-fauna quality in the Sahel.

\section{MATERIALS AND METHODS \\ Description of the study sites}

The study sites were located in the North and Central-North Regions of Burkina Faso. Oula and Boursouma are located in Ouahigouya district and fall within the regreening zone while Lebda and Koalma in Kaya district belong to the degrading zones according to previous studies (Anyamba and Tucker, 2005; Hickler et al., 2005; Fensholt et al., 2012; Dardel et al., 2014) (Figure 1). All the sites belong to the semi-arid climate zone that has been severely damaged by the different droughts episodes of 1972-73 and 1983-84. The vegetation type encountered is shrub savannah, and the mean annual rainfall varies between 500 and $600 \mathrm{~mm}$. Monthly mean maximum and minimum temperatures range from 32 to $42{ }^{\circ} \mathrm{C}$ and from 16 to $29^{\circ} \mathrm{C}$, respectively. The main soils are: (i) tropical ferruginous types, poorly to fully leached (ii) degraded holomorphic soils comprising solonetz (iii) tropical eutrophic brown soils overlying high clay parent material and poorly evolved erosional soil overlying gravelly material (CILSS et OMM, 2001). 


\section{Site selection}

Sites were selected based on thetrends in NDVI and residual NDVI from 1982 to 2008 from Herrmann et al. (2005). The sites have roughly the same population density (Ouedraogo, 2010) and are located in the same agro-ecological zone where soil water conservations technologies are used intensively (Figure 1). According to Eklundh and Olsson (2003), Anyamba and Tucker (2005), Olsson et al. (2005), Hickler et al. (2005), and Turcker et al. (2005), the areas surrounding Ouahigouya are experiencing a vegetation re-greening trend while areas around Kaya are in continuous degradation.

\section{Sampling}

Soil macro-fauna was assessed using the Tropical Soil Biology and Fertility (TSBF) method (Anderson et Ingram, 1993) and the sampling procedure was done during the rainy season (September 2013) in each plot. TSBF method consists of isolating a monolith of soil after randomly selecting a small square in the different types of land uses (Shallow land, cropland, forest and degraded land) in each site. The monoliths measured $25 \mathrm{~cm} \times 25 \mathrm{~cm}$ sizes and $30 \mathrm{~cm}$ soil depth.

The monolith was shared into four strata: 0-5 cm, 5-10 cm, $10-20 \mathrm{~cm}$ and $20-30$ $\mathrm{cm}$. Each stratum was spread on a tray and macro invertebrate picked up by hand. The macro-invertebrates visible to eye were removed, fixed in alcohol of $90^{\circ}$ and brought to the laboratory for identification. The identification was achieved through a binocular microscope and an identification key. They were then grouped according to the taxonomic group (earthworms, ants, termites, beetles, millipedes, spiders, cockroaches and snails). Individuals not belonging to these groups are classified in a separate group called others.

Four repetitions were taken for each land use type in each site. In all, sixty four soil samples were used for the assessment.

\section{Data analysis}

The raw data from the treatment of monoliths gave the number of soil macrofauna per sample, per land use type, per zone and per taxon. They allowed the determination of parameters for the appreciation of soil fauna, such as the abundance and diversity. The macro-fauna abundance, a quantitative factor, was expressed by the average number of individuals collected per plot and densities (mean number of individuals per unit area). Macro-fauna species diversity was assessed using the Shannon-Weaver index $\left(\mathrm{H}^{\prime}\right)$ and the equitability (E) for each plot. The H' value takes into account the number of taxa encountered (s). Its value is given by the following equation:

$\mathrm{H}^{\prime}=-\sum_{i=1}^{s} P i \ln (\mathrm{Pi})$

where $P_{i}$ is the proportion of species $i$ with respect to the total number of species in the study plot, which is calculated as follows: $P_{i}=\frac{n_{i}}{N}$

where $n_{i}$ is the number of individuals for species $\mathrm{i}$ and $\mathrm{N}$ is the total effective; $\mathrm{s}=$ total number of taxa encountered on the plot. $\mathrm{H}^{\prime}$ is zero when only one group is represented and its value is maximal when all groups have the same abundance. The equitability (E) or regularity measures the fair distribution of taxa and allows the comparison of populations with different numbers of taxa. The objective was to observe the balance of the populations. Its value is given by the following formula: $\mathrm{E}=\frac{H^{\prime}}{\ln (s)}$

The equitability tends to 0 when a taxon dominates widely, and is equal to 1 when all groups are evenly represented.

Data were prepared for analysis of variance using Genstat (Edition 4) to determine the influence of re-greening on the abundance, composition and diversity of macro-fauna and trophic functions of the different groups of macro-fauna extracts in each zone. The means comparison was made using Newman-Keuls test with the significance probability of $5 \%$. 


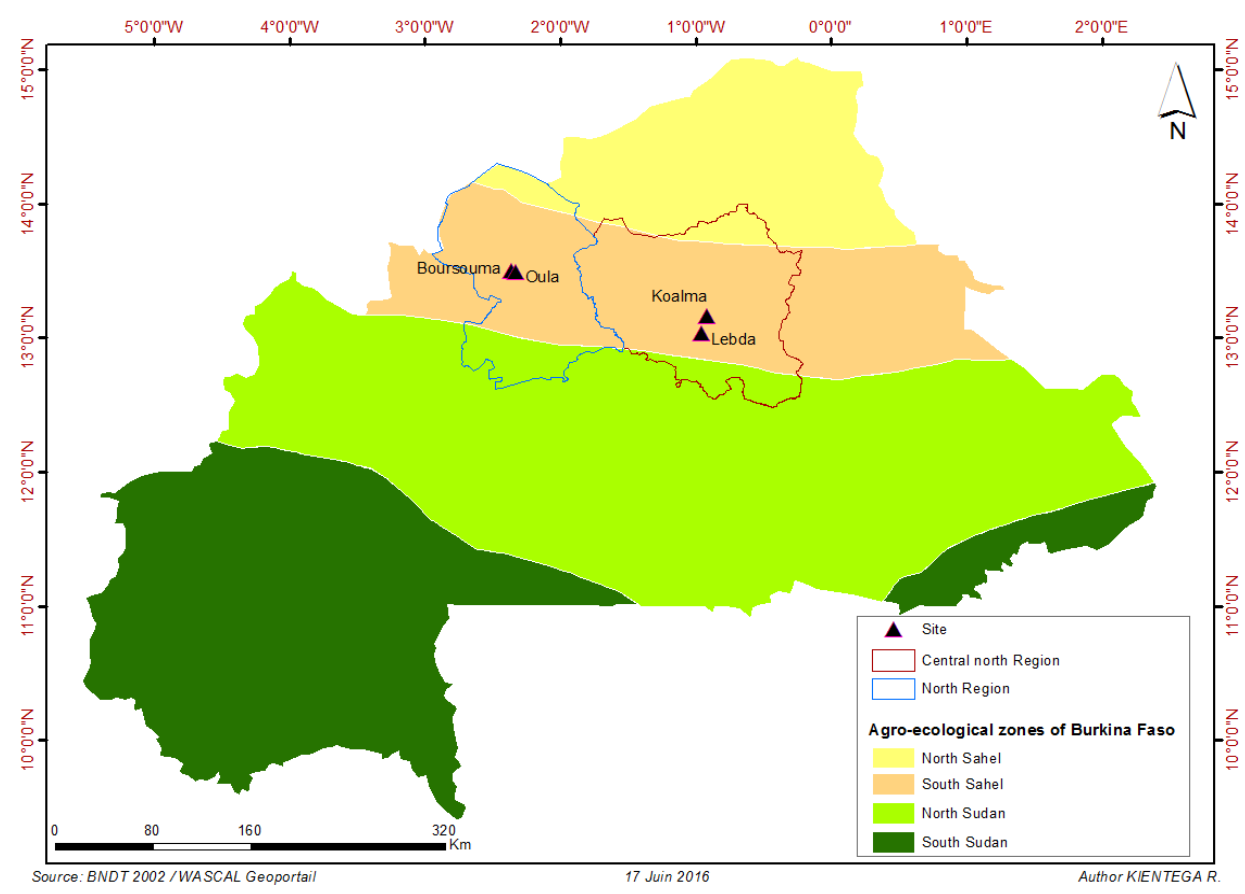

Figure 1: Burkina Faso Agro-ecological zones and Site location map.

\section{RESULTS}

Abundance and composition of macrofauna in contrasted ecosystem

A total of 1599 macro-invertebrates were collected in both zone and in all land use types of which $64.92 \%$ individuals belong to the re-greening zone. The average density is important in the degraded land (305.92 ind $\left./ \mathrm{m}^{2}\right)$ and shallow land $\left(80.42 \mathrm{ind} / \mathrm{m}^{2}\right)$ at Oula. In croplands and forest, the average densities of macro-invertebrates were 46.05 $\mathrm{ind} / \mathrm{m}^{2}$ and $84.50 \mathrm{ind} / \mathrm{m}^{2}$ respectively in Boursouma and Koalma (Table 1).

The inventory showed a clear dominance of Arthropoda phylum which represented $92.37 \%$ from which $60.85 \%$ of individuals were found in the re-greening zone and $31.52 \%$ in the degrading zone. The class of Insecta dominated with $87.76 \%$ of individuals with $59.03 \%$ in the re-greening zone and $28.64 \%$ in degrading zone. In both zones, the order of Isoptera prevailed among insecta with $46.97 \%$ and $15.82 \%$ of individuals, respectively in the re-greening and degrading zones, followed by
Hymenoptera with $8.88 \%$ in the degradation zone and $6.57 \%$ in the re-greening zone.

There was a large dominance of individuals in land use types classified as degraded land $(31.21 \%)$ and shallow land $(20.33 \%)$ in the re-greening zone. However, in the degrading zone, the dominance of individuals was found in cropland and shallow land with $11.63 \%$ and $11.01 \%$ respectively. With regards to order, Isoptera, Hymenoptera and Coleoptera were the three dominant orders in all sites. Isoptera order was dominant at Boursouma (Shallow land $4.38 \%$, cropland $4.88 \%$ ), Oula (Shallow land $5.13 \%$, degraded land 29.14\%) and Koalma (Forest 4.69\%), while, Hymenoptera order was dominant at Oula (shallow land 5.19\%) (Table 2 ). The re-greening zone sheltered twice the number of macro-fauna found in degrading zone irrespective to soil depth (Table 3).

\section{Diversity of soil macro-fauna}

Species richness varied from 19 to 33 species per site. The shallow land and cropland in the re-greening zone had the 
highest number of species (18) and the degraded land of Boursouma and forest of Lebda were the poorest with respectively 8 and 2 species. The differences were significant for species number, family number and order number with high values in shallow land at Boursouma and Oula (Table 4). For Weaver Shannon diversity index and equitability, the differences were not significant between zones and sites. But there was a trend of land use effect $(\mathrm{p}=0.08)$ with $\mathrm{E}$ and $\mathrm{H}^{\prime}$ highest values in shallow and cropland (Table 5).

\section{Contribution to macro-fauna to soil function}

All the sites had different trophic groups necessary to soil function and soil improvement capacity to support disturbance. Predators include Arachnida, Chilopoda and Coleoptera (adult and larva), decomposers comprising Earthworms (epigeic), Diplopoda (millipede), Coleoptera and Isopoda, the Ecosystem engineers such as Ants and Earthworms, and phytophage comprising Coleoptera (adult and larva) and Hemiptera. Coleoptera and Earthworm are represented respectively in 3 and 2 trophic groups (Table $6)$.

Table 1: Macro-fauna density according to land use (ind $\left./ \mathrm{m}^{2}\right)$.

\begin{tabular}{lcccc}
\hline & Boursouma & Oula & Lebda & Koalma \\
\hline Shallow land & 52.40 & 80.42 & 74.67 & 25.04 \\
Cropland & 46.05 & 18.00 & 44.36 & 45.47 \\
Degraded land & 16.00 & 305.92 & 17.23 & 37.14 \\
Forest & 16.67 & 30.61 & 24.00 & 84.50 \\
\hline
\end{tabular}

Table 2: Percentage of individual (\%) in the three dominates order per land use.

\begin{tabular}{llcccc}
\hline \multirow{3}{*}{ Boursouma } & Orders & Shallow land & Cropland & Forest & Degraded land \\
\hline \multirow{3}{*}{ Oula } & Coleoptera & 0.19 & 1.06 & 0.44 & 0.38 \\
& Isoptera & 4.38 & 4.88 & 0.69 & 0.75 \\
\hline \multirow{3}{*}{ Koalmaoptera } & 0.69 & 0.69 & 0.75 & 0.19 \\
& Isoptera & 5.13 & 0.50 & 1.56 & 29.14 \\
& Hymenoptera & 5.19 & 0.31 & 0.06 & 0.06 \\
\hline \multirow{3}{*}{ Lebda } & Coleoptera & 0.56 & 0.50 & 0.56 & 0.38 \\
& Isoptera & 0.88 & 3.56 & 4.69 & 0.38 \\
& Hymenoptera & 0.06 & 3.19 & 0.19 & 1.25 \\
& Coleoptera & 0.81 & 0.19 & 0.13 & 0.56 \\
& Isoptera & 3.00 & 2.44 & 0.13 & 0.19 \\
& Hymenoptera & 3.75 & 0.63 & 0.13 & 0.25 \\
\hline
\end{tabular}


Table 3: Percentage of individuals according to the soil depth.

\begin{tabular}{|c|c|c|}
\hline Depth & Degrading zone $(\%)$ & Re-greening zone (\%) \\
\hline $0 \_5 \mathrm{~cm}$ & 34.39 & 25.49 \\
\hline $5 \_10 \mathrm{~cm}$ & 22.35 & 20.86 \\
\hline $10 \_20 \mathrm{~cm}$ & 29.09 & 25.85 \\
\hline $20 \_30 \mathrm{~cm}$ & 14.16 & 27.81 \\
\hline
\end{tabular}

Table 4: Species, family and order number according to land use.

\begin{tabular}{llccccc}
\hline & Sites & Shallow land & Cropland & Forest & Degraded land & Probability \\
\hline \multirow{3}{*}{ Species } & Boursouma & 7.00 & 8.50 & 4.25 & 2.25 & 0.05 \\
number & Oula & 8.00 & 4.50 & 4.75 & 3.75 & 5.00 \\
& Koalma & 3.75 & 5.00 & 5.00 & 4.50 & \\
& Lebda & 5.50 & 3.50 & 1.00 & 2.25 & 0.05 \\
Family & Boursouma & 6.25 & 6.50 & 3.75 & 4.50 & 0.02 \\
number & Oula & 6.25 & 3.25 & 4.25 & 4.75 & \\
& Koalma & 3.50 & 4.25 & 4.50 & 1.75 & \\
\hline \multirow{3}{*}{ Order } & Lebda & 5.00 & 3.25 & 1.00 & 2.25 & \\
number & Ooursouma & 5.00 & 5.50 & 2.75 & 2.00 & \\
& Koalma & 4.75 & 2.75 & 2.50 & 3.50 & \\
\hline
\end{tabular}

Table 5: Diversity index and equitability of macro-fauna.

\begin{tabular}{|c|c|c|c|c|c|c|}
\hline & Sites & Shallow land & Cropland & Forest & Degraded land & Probability \\
\hline \multirow{3}{*}{ Diversity } & Koalma & 1.00 & 1.22 & 1.44 & 1.38 & \multirow{3}{*}{ NS } \\
\hline & $\begin{array}{l}\text { Lebda } \\
\text { Boursouma }\end{array}$ & $\begin{array}{l}1.61 \\
1.89\end{array}$ & $\begin{array}{l}1.18 \\
1.94\end{array}$ & $\begin{array}{l}0.38 \\
1.15\end{array}$ & $\begin{array}{l}1.15 \\
0.68\end{array}$ & \\
\hline & Oula & 1.88 & 1.19 & 1.37 & 0.86 & \\
\hline Means & & 1.60 & 1.38 & 1.09 & 1.01 & 0.08 \\
\hline \multirow{4}{*}{ Equitability } & Koalma & 0.83 & 0.88 & 1.04 & 0.96 & \multirow{4}{*}{ NS } \\
\hline & Lebda & 1.07 & 0.86 & 0.54 & 0.77 & \\
\hline & Boursouma & 1.02 & 1.06 & 0.77 & 0.75 & \\
\hline & Oula & 1.03 & 0.85 & 0.94 & 0.61 & \\
\hline Means & & 0.99 & 0.91 & 0.82 & 0.77 & 0.59 \\
\hline
\end{tabular}


Table 6: Collected macro-fauna trophic group.

\begin{tabular}{llcccc}
\hline & & Boursouma & Oula & Koalma & Lebda \\
\hline Predators & Arachnida & + & & + & + \\
& Chilopoda & + & + & + & \\
& Coleoptera (adult and larva) & + & + & + & + \\
\hline \multirow{2}{*}{ Decomposer } & Earthworms (epigeic) & + & + & + & + \\
& Diplopoda (millipede) & + & + & + & + \\
& Coleoptera & + & + & + & + \\
& Isopoda & + & + & + & + \\
\hline Ecosystem & Ants & + & + & + & + \\
engineer & Earthworms (aneciques and & + & + & + & + \\
& endoge) & & & & \\
\hline Phytophage & Coleoptera (adult and larva) & + & + & & + \\
& Hemiptera & + & + & & + \\
\hline +: presence of species & & & & &
\end{tabular}

\section{DISCUSSION}

Importance and contribution of soil macro fauna to ecosystem functions

Environment conditions the presence and species types of macro-fauna (Doamba et al., 2011). Cropland and shallow land are environment where trees and a low sunlight facilitate macro-fauna proliferation. Hence, this explains the high densities of macro-fauna in the cropland and shallow land. The presence of macro-fauna in the soil contributes to the increase in soil available phosphorus content by $68 \%$ (Ouedraogo et al., 2014) and to enhance nutrient use efficiency and crop water uptake (Ouedraogo et al., 2006). Moreover, macro-fauna build up soils structure that gives them a specific architecture (Lavelle, 2002). Soil organisms also have the ability to regenerate compact structures (Hallaire et al., 2004) which allows degraded land to recover its vegetation and become a green zone.

The density and diversity of macrofauna decreased in degraded land, compacted and acidified land due to the hostility of the environment that reduces their number. But, at Oula in the re-greening zone, the degraded land regenerated with a high density of macrofauna. Isoptera order, ecosystems engineers are dominants in the re-greening zone. According to Lavelle et al. (1994), these are species that are more resistant to disruption. These species colonize degraded land allowing their rehabilitation. Generally, ants are the most abundant species in the forest and, for Tondoh (2008), ants, Diplopoda, earthworms and the beetles have proven to be the most sensitive macro-invertebrates to forest degradation and thus can be used as "bio-indicators" of forest conservation status. Indeed, soil biodiversity give to soil, resistance and resilience to disturbance and stress (Brussaard et al., 2007).

\section{Macro-fauna and ecosystems stability}

Ecosystem health involves the provision of ecosystem services that can improve livelihood. Activity of soil fauna 
creates soil mixing, which allows significant soil volume traffic by surfacing rich mineral horizons and burying organic upper horizons. We found a significant proportion of macrofauna in soil upper layer $(0-10 \mathrm{~cm})$ in the regreening zone due to better soil conditions.

The presence of healthy macro-fauna population is important for water infiltration (Sarr et al., 2001), the sustainability of soil functions and suitable agricultural ecosystem is dependent on soil organisms (Barrios, 2007). It is evident that ecosystem engineers increase porosity by gallery formations that are very important for soil aeration (IlboudoTapsoba et al., 2011). In addition, macrofauna offers preferential pathways to the roots, stability of the ecosystem and contributes to water retention (earthworms, ants, termites) and, soil restoration (Milau et al., 2015). The effects of macro-fauna on the dynamics of soil organic matter improve soil fertility and increases yields (Lavelle et al., 2001).

In re-greening zones, macro-fauna is more diverse, contributing to soil quality improvement. The presence of a microclimate facilitates their migration to the soil surface layers. For ecosystem regulation, predators participate in biological control and balance population, while decomposers recycle the organic matter, and the ecosystems engineer control the structuration and bioturbation of the soils. Their complementary functions allow the ecosystem to resist to disturbances.

\section{Conclusion}

The improvement of trees densities in some land use types was not accompanied by more macro-fauna abundance and diversity. In the re-greening zones, macro-fauna was more diverse and abundant than in the degrading zones. Soil macro-fauna contributed to improve soil quality and functions.

The results showed that the improvement in some landscape units did not give a positive impact on the abundance and diversity of soil macro-fauna, but macro-fauna was composed of many species, families and orders in each land use type and each site. These results provide a basis for monitoring soil quality in the Sahel of Burkina Faso. Further studies are needed to find out how macro-fauna will evolve with the evolution of re-greening. Actually, the improvement of the vegetation cover was not accompanied with a very strong macro-fauna community, but the existence of different trophic groups will boost the functioning of ecosystems and may improve soil quality and yield in the coming years.

\section{COMPETING INTERESTS}

All authors declare that they have no competing interests.

\section{AUTHORS' CONTRIBUTIONS}

OMS collected the data, run the statistical analysis and wrote the manuscript (20\%). KO contributed to design the methodology (all authors agreed on the method to use for sampling, sampling period and site choice). He also contributed to the statistical analysis and provided comments to the manuscript $(15 \%)$. IO participated in the writing and improvement of the manuscript. He also contributed to the language checking (15\%). SS/K, JB and LG read and improved the discussion section. They also provided logistical and financial assistances during the field work (10\% each). MT was helpful in the laboratory works (10\%). SP and NPZ contributed to write the methodology (5\% to each person).

\section{REFERENCES}

Anderson JM, Ingram JSI. 1993. Tropical Soil Biology and Fertility: a Handbook of Metsu. CAB International: Oxford; 221. 
Anyamba A, Tucker CJ. 2005. Analysis of Sahelian vegetation dynamics using NOAA AVHRR NDVI data from 19812003. J. Arid Environ., 63(3): 596-614. DOI: 10.1016/j.jaridenv.2005.03.007

Barrios E. 2007. Soil biota, ecosystem services and land productivity. Ecol. Econ., 64: 269-85. DOI:10.1016/ j.ecolecon.2007.03.004

Botoni E, Reij C. 2009. La Transformation Silencieuse de l'Environnement et des Systèmes de Production au Sahel: Impacts des Investissements Publics et Privés Dans la Gestion des Ressources Naturelles. Vrije Universiteit Amsterdam (VUA) and Comité permanent Inter-Etats de Lutte contre la Sécheresse dans le Sahel (CILSS): Amsterdam, The Netherland ; 63.

Brussaard L, De Ruiter P, Brown G. 2007. Soil biodiversity for agricultural sustainability. Agric. Ecosyst. Environ., 121: $\quad 233244$. DOi:10.1016/j.agee.2006.12.013

CILSS, OMM. 2001. Les aptitudes agricoles et pastorales des sols dans les pays du CILSS, 173p.

Dardel C, Kergoat L, Hiernaux P, Mougin E, Grippa M, Tucker CJ. 2014. Re-greening Sahel: 30 years of remote sensing data and field observations (Mali, Niger). Remote Sens. Environ., 140: 350-364. DOI: http://dx.doi.org/10.1016/ j.rse.2013.09.011

Doamba SMF, Nacro HB, Sanon A, Sedogo M. 2011. Effet des cordons pierreux sur l'activité biologique d'un sol ferrugineux tropical lessivé (Province du Kouritenga au Burkina Faso). Int. J. Biol. Chem. Sci., 5(1): $\quad 304-313 . \quad$ DOI : www.ajol.info/index.php/ijbcs/article/do wnload/68106/56196

Eklundh L, Olsson L. 2003. Vegetation index trends for the African Sahel 1982-1999.
Geophys. Res. Lett., 30(8): 1430. DOI: 10.1029/2002GL016772

Fensholt R, Langanke T, Rasmussen K, Reenberg A, Prince SD, Tucker C, Scholes RJ, Le QB, Bondeau A, Eastman R, Epstein H, Gaughan EA , Hellden U, Mbow C, Olsson L, Paruelo J, Schweitzer C, Seaquist J, Wessels K. 2012. Greenness in semi-arid areas across the globe 1981-2007-An Earth observing satellite based analysis of trends and drivers. Remote Sens. Environ., 121: 144158. DOI:10.1016/j.rse.2012.01.017

Gajbhiye KS, Mandal C. 2000. AgroEcological Zones, their Soil Resource and Cropping Systems, status of farm mechanization in India, 32p.

Hallaire V, Lamandé M, Heddadj D. 2004. Effet de l'activité biologique sur la structure des sols soumis à différentes pratiques culturales. Impacts sur leurs propriétés de transfert. Etude et Gestion des Sols, 11(1): 47-58.

Herrmann SM, Anyamba A, Tucker CJ. 2005. Recent trends in vegetation dynamics in the African Sahel and their relationship to climate. Glob. Environ. Change, 15: 394404. DOI: 10.1016/j.gloenvcha. 2005.08.004

Hickler T, Eklundh L, Seaquist JW, Smith B, Ardö J, Olsson L, Sykes MT, Sjöström M. 2005. Precipitation controls Sahel greening trend. Geogr. Res. Lett., 32: DOI:10.1029/2005GL024370

Hountondji YC, Sokpon N, Ozer P. 2006. Analysis of vegetation trends using low resolution remote sensing data in Burkina Faso (1982-1999) for the monitoring of desertification. Int. J. Remote Sens, 27(5): 871-884.

DOI: $10.1080 / 01431160500382782$

Ilboudo-Tapsoba E, Tankoano H, Ouedraogo M, Dicko IO, Sanon A. 2011. Diversité des insectes actifs au sol dans quatre 
écosystèmes de bas-fonds du Burkina Faso : importance pour la détermination de bio-indicateurs caractérisant ces milieux. Int. J. Biol. Chem. Sci., 5(2): 724-738. http://dx.doi.org/10.4314/ ijbcs.v5i2.72146

Lavelle P. 2002. Functional domains in soils. Ecol. Res., 17: 441-50. DOI: 10.1046/j.14401703.2002.00509.x

Lavelle P, Barros E, Blanchart E, Brown G, Desjardins T, Mariani L, Rossi JP. 2001. SOM management in the tropics: Why feeding the soil macrofauna? Nutr. Cycl. Agroecosyst., 61: 53-61. DOI: 10.1023/A:1013368715472

Lavelle P, Dangerfield JM, Eschenbrenner V, Lopez-Hernandez D, Pashanasi B, Brussaard L. 1994. The relationship betwen soil macrofauna and tropical soil fertility. In The Biological Management of Tropical Soil Fertility, Woomer PL, Swift MJ (ed); 137-169.

Milau EF, Kachaka SC, Aloni KJ, Mvumbi MN, Francis F. 2015. Incidence de la déforestation sur les catégories écologiques des vers de terres dans le domaine et Reserve de chasse de BomboLumene (Kinshasa). Tropicultura, 33(3): 209-217.

Olsson L, Eklundh L, Ardö J. 2005. A recent greening of the Sahel-trends, patterns and potential causes. J. Arid Environ., 63: 556-566. DOI:10.1016/j.jaridenv.2005. 03.008

Ouedraogo E, Mando A, Brussaard L. 2006. Soil macrofauna affect crop nitrogen and water use efficiencies in semi-arid West Africa. Eur. J. Soil Biol., 42: S275-S7. DOI:10.1016/j.ejsobi.2006.07.021

Ouédraogo I. 2010. Land Use Dynamics and Demographic Change in Southern Burkina Faso. PhD Thesis, Alnarp, Sweden University of Agricultural Sciences, 64 p.
Ouédraogo I, Runge J, Eisenberg J, Barron J, Sawadogo / Kaboré S. 2014. The ReGreening of the Sahel: Natural Cyclicity or Human-Induced Change? Land, 3: 1075-1090. DOI: 10.3390/land3031075.

Ouédraogo J, Nacro HB, Ouédraogo E, Youl S, Sédogo MP. 2014. Amélioration de la disponibilité du phosphore par la gestion de la macrofaune du sol: cas d'un lixisol en zone semi-aride du Burkina Faso. Int. J. Biol. Chem. Sci., 8(4): 1838 - 1846. DOI : http://dx.doi.org/10.4314/ijbcs. v8i4.41

Ouédraogo J, Ouédraogo E, Nacro HB. 2014: Effet de l'interaction entre des modes de gestion de fertilité et la macrofaune sur la productivité du niébé et du sorgho en zone nord soudanienne du Burkina Faso. Int. J. Biol. Chem. Sci., 8(1): 104-114. DOI : http://dx.doi.org/10.4314/ijbcs. v8i1.10

Ozer P. 2009. Quand le désert avance. La Libre Belgique. http://hdl.handle.net/ 2268/17638

Ozer P, Gassani J, Hountondji YC, Niang AJ, Karimou A. 2007. La désertification est elle en recul au Sahel ? Bois et Forêts des Tropiques, 293(3): 23-28. http://hdl. handle.net/2268/15838

Sarr M, Agbogba C, Russell-Smith A, Masse D. 2001. Effects of soil faunal and woody shurbs on water infiltration rates in a semi-arid fallow of Senegal. Appl. Soil Ecol., 16: 283-90. DOI:10.1016/S09291393(00)00126-8

Savadogo OM, Ouattara K, Barron J, Ouédraogo I, Gordon L, Enfors E, Zombre NP. 2015. Etats des écosystèmes sahéliens: reverdissement, perte de la diversité et qualité des sols. Afrique Science, 11(5): 433446. http://www.afriquescience.info/document .php?id=5422. ISSN 1813-548X 
Savadogo OM, Ouattara K, Pare S, Ouedraogo I , Sawadogo-Kaboré S, Barron J, Zombre NP. 2016. Structure, composition spécifique et diversité des ligneux dans deux zones contrastées en zone Sahélienne du Burkina Faso ». VertigO - la Revue Electronique en Sciences de l'Environnement, 16(1) http://vertigo.revues.org/17282. DOI: 10.4000/vertigo. 17282

Sendzimir J, Reij C, Magnuszewski P. 2011. Rebuilding resilience in the Sahel: Regreening in the Maradi and Zinder regions of Niger. Ecol. Soc., 16(1): 29. DOI: http://dx.doi.org/10.5751/ES04198-160301

Tondoh JE. 2008. Effet de la mise en culture des forêts secondaires sur les peuplements de macroinvertébrés du sol dans la zone de contact forêt-savane de
Côte d'Ivoire. Sci. \& Nat., 4(2): 197-204.

DOI: $\quad$ http://dx.doi.org/10.4314/ scinat.v4i2.42144

Traore M, Lompo F, Ayuke F, Ouattara B, Ouattara K, Sedogo M. 2012. Influence des pratiques agricoles sur la macrofaune du sol : cas de l'enfouissement de la paille et du fumier. Int. J. Biol. Chem. Sci., 6(4): 1761-1773. DOI: http://dx.doi.org/10.4314/ijbcs.v6i4.31

Tucker CJ, Pinzon JE, Brown ME, Slayback DA, Pak EW, Mahoney R. 2005. An extended AVHRR 8-Km NDVI dataset compatible with Modis and Spot vegetation NDVI data. Int. J. Remote Sens., 26(20): 4485 - 4498. DOI: $10.1080 / 01431160500168686$ 